Journal of Pharmaceutical Science and Medical Research

Vol. 4, No.1, Februari 2021, hal 32 - 38

ISSN (print): 2614-4840 ISSN (online): 2614-6118

Avaliable online at: http://e-journal.unipma.ac.id/index.php/pharmed

\title{
Pengkajian Administrasi dan Farmasetis Resep Anak di Apotek G Madiun
}

\author{
Ayu Palupi ${ }^{1}$, Rita Septiana ${ }^{2}$, Khotimatul Khusna ${ }^{3}$ \\ 1)Mahasiswa Program Studi Farmasi Universitas Sahid Surakarta \\ ${ }^{2,3)}$ Dosen Program Studi Farmasi Universitas Sahid Surakarta \\ Jl. Adi Sucipto No.154, Jajar, Kec. Laweyan, Kota Surakarta \\ e-mail: ${ }^{2)}$ ritaseptiana0@gmail.com
}

\begin{abstract}
Abstrak
Pengkajian resep merupakan salah satu kegiatan pelayanan kefarmasian yang bertujuan untuk menurunkan kesalahan pengobatan dan meningkatkan keselamatan pasien. Penelitian ini bertujuan untuk mengetahui persentase kelengkapan penulisan resep pada pasien anak di Apotek G Kota Madiun dari aspek administrasi dan farmasetik. Penelitian ini merupakan jenis penelitian deskriptif observasional dengan pengambilan sampel secara acak sederhana (simple random sampling). Sampel penelitan adalah resep pasien anak usia 2 sampai dengan 12 tahun yang masuk di Apotek G periode Juni-Agustus 2019. Dalam penelitian ini, jumlah resep yang dikaji sebanyak 300 resep. Penelitian ini menunjukkan, berdasarkan aspek administarsi didapatkan hasil sebagai berikut : kelengkapan penulisan nama dokter sebesar $100 \%$, tempat atau alamat dokter $100 \%$, tanda R/ $100 \%$, nama obat $100 \%$, kekuatan obat $100 \%$, jumlah obat $100 \%$, aturan pakai obat $100 \%$, tanda tangan atau paraf dokter $99,6 \%$, no.telepon dokter $99,3 \%$, nama pasien $99 \%$, tanggal penulisan resep $97 \%$, SIP dokter $81,6 \%$, umur pasien $62 \%$, alamat pasien $28,3 \%$, berat badan pasien $2,6 \%$, tinggi badan pasien $0,67 \%$ dan jenis kelamin pasien $0 \%$. Berdasarkan pengkajian farmasetis menunjukkan kesesusian antara bentuk sediaan dan pasien $100 \%$, stabilitas obat $100 \%$, cara pakai obat $100 \%$, inkompatibilitas dalam resep $0 \%$. Dapat disimpulkan bahwa resep anak yang masuk di apotek G sudah memenuhi ketentuan kelengkapan farmasetis, tetapi belum memenuhi ketentuan kelengkapan administratif.
\end{abstract}

Kata kunci: Pengakajian, Skrining, Telaah, Resep, Kelengkapan

\section{Administration and Pharmacetic Study of Prescription Children at Pharmacy G Madiun}

\begin{abstract}
Prescription assessment is one of pharmaceutical service activities that aims reduce medication errors and improve patient safety. This study aims to see administration and pharmaceuticals completeness on children's prescriptions at Pharmacy G Madiun city. This research is observational descriptive, with simple random sampling. Sample is childrens prescription who received at $G$ pharmacy period juni-agustus 2019. In this study, prescriptions studied was 300 recipes. This research shows, based on administrative aspects, the following results were obtained : completeness doctors name $100 \%$, doctors address $100 \%$, sign $\mathrm{R} / 100 \%$, drugs name $100 \%$, drugs strength $100 \%$, drugs amount $100 \%$, drugs rule used $100 \%$, signature or doctors initial $99,6 \%$, doctors telephone number $99,3 \%$, patients name $99 \%$, prescriptions date $97 \%$, doctors SIP $81,6 \%$, patients age $62 \%$, patients address $28,3 \%$, patients weight $2,6 \%$, patients height $0,67 \%$ and patients gender $0 \%$. Based on pharmaceutical assessment showed suitability of dosage form and patients $100 \%$,
\end{abstract}


drugs stability $100 \%$, how to drugs use $100 \%$, prescription incompatibility $0 \%$. It can be concluded that the child's prescription that was received at G pharmacy has met the requirements for pharmaceutical completeness, but has not met the requirements for administrative completeness.

Keywords: Recitation, Screening, Review, Prescription, Completeness

\section{Pendahuluan}

Pengkajian atau yang sering disebut skrining merupakan kegiatan yang bertujuan untuk menganalisa adanya masalah terkait obat dalam proses pelayanan resep. Kegiatan skrining merupakan upaya pencegahan terjadinya medication error atau kesalahan dalam pemberian obat. Pengkajian dan pelayanan resep dilakukan untuk semua resep yang diterima tanpa ada kriteria khusus pasien (Kemenkes RI, 2019). Pengkajian resep meliputi kajian kelengkapan administrasi, kajian kesesuaian farmasetik dan pertimbangan klinis (Kemenkes RI, 2016). Apoteker dapat berperan dalam upaya meminimalisir terjadinya medication error yaitu dengan melakukan pengkajian resep berdasarkan standar yang telah ditetapkan (Ismaya et al., 2019).

Resep adalah permintaan tertulis dari dokter atau dokter gigi, kepada apoteker, baik dalam bentuk paper maupun electronic untuk menyediakan dan menyerahkan obat bagi pasien sesuai peraturan yang berlaku (Kemenkes RI, 2014). Resep harus memuat cukup informasi yang memudahkan apoteker atau tenaga teknis kefarmasian mengerti dan memahami obat apa yang akan diserahkan kepada pasien. Berdasarkan praktik dilapangan, permasalahan terkait resep dan peresepan masih banyak ditemui. Banyak faktor yang menjadi penyebab terjadinya permasalahan dalam penulisan resep. Dokter penulis resep hendaknya menulis resep sesuai dengan peraturan perundang-undangan yang berlaku (Jas, 2009).

Dalam praktiknya masih ditemukan ketidaklengkapan dalam penulisan resep. Penelitian sebelumnya tentang kajian kelengkapan resep pediatri rawat jalan menunjukan ketidaksesuaian berdasarkan aspek farmasetis sebesar $78,7 \%$, ketidaksesuaian klinik 16,61\% administrasi 4,69\% (Piliarta et al., 2012). Penelitian di Apotek CS Farma menunjukkan hasil pengkajian admintrasi yang meliputi kelengkapan penulisan nama pasien sebesar $99,22 \%$, umur pasien $88,05 \%$, jenis kelamin $9,09 \%$, berat badan $0 \%$, nama dokter $3,64 \%$, surat izin praktik dokter $0 \%$, tanggal resep $97,92 \%$, alamat dokter $100 \%$, nomor telepon dokter $0,26 \%$ dan paraf dokter $6,23 \%$. Berdasarkan pengkajian farmasetis bentuk sediaan $69,61 \%$, kekuatan sediaan $57,66 \%$, stabilitas obat $100 \%$ dan kompatibilitas obat $100 \%$. Peneliti menyimpulkan bahwa resep yang ada di Apotek CS Farma bulan Juni-Desember 2018 belum lengkap secara administratif dan farmasetik (Rauf et al., 2020).

Resep pasien anak dipilih sebagai obyek penelitian karena penggunaan obat untuk kelompok anak membutuhkan perhatian khusus karena terkait dengan perbedaan laju perkembangan organ tubuh serta sistem enzim yang bertanggungjawab terhadap metabolisme dan ekskresi obat. Salah satu hal yang harus diperhatikan dalam pemberian obat pada pasien anak adalah dosis yang optimal. Bioavalaibilitas, farmakokinetik, farmakodinamik, efikasi dan informasi tentang efek samping dapat berbeda secara bermakna antara pasien pediatri dan pasien dewasa karena adanya perbedaan usia, fungsi organ dan status penyakit. Penggunaan obat pada pasien pediatri perlu perhatian khusus dan harus dipahami serta diterapkan oleh apoteker agar tidak terjadi kesalahan dalam penggunaan obat (Depkes RI, 2009). Berdasarkan latar belakang tersebut, peneliti melakukan penelitian tentang pengkajian resep secara adminitrasi dan farmasetis terhadap resep anak yang masuk di Apotek $G$ Kota Madiun pada bulan Juni sampai Agustus 2019. 


\section{Metode Penelitian}

Penelitian ini merupakan jenis penelitian deskriptif observasional dengan. Populasi adalah semua resep yang masuk di Apotek Garuda Madiun, periode bulan Juni sampai dengan Agustus 2019. Sampel merupakan bagian dari populasi yang memenuhi kriteria inklusi dan eksklusi. Kriteria inklusi penelitian adalah resep pasien anak usia 2 sampai dengan 12 tahun, sedangkan kriteria eksklusinya adalah resep yang tidak terbaca. Jalannya penelitian diawali dengan penentuan masalah dalam penelitian, penyusunan proposal dan perijinan ke pihak apotek, selanjutnya adalah proses pengambilan data dan dilajutkan dengan pengolahan data dan penyusunan laporan. Instrument yang digunakan sebagai parameter/pedoman pengkajian resep adalah Peraturan Menteri Kesehatan Republik Indonesia No.73 tahun 2016, tentang Standar Pelayanan Kefarmasian di Apotek.

\section{Hasil dan Pembahasan}

Pada penelitian ini dilakukan pengkajian secara administrasi dan farmasetis terhadap 300 resep anak yang masuk di Apotek G Kota Madiun periode Juni-Agustus 2019 yang memenuhi kriteria inklusi. Pengkajian resep dilakukan menggunakan pedoman Peraturan Menteri Kesehatan Republik Indonesia No.73 tahun2016, tentang Standar Pelayanan Kefarmasian di Apotek.

\section{Analisa Resep Berdasarkan Kajian Administrasi}

Tabel 1. Pengkajian Admininstrasi Resep Anak yang Masuk di Apotek G Kota Madiun Periode Juni sampai Agustus 2019

\begin{tabular}{|c|c|c|c|c|c|}
\hline \multirow{3}{*}{ No } & \multirow{3}{*}{ Aspek Administrasi } & \multicolumn{4}{|c|}{$\begin{array}{l}\text { Kelengkapan Administrasi } \\
\qquad(\mathrm{n}=300)\end{array}$} \\
\hline & & \multicolumn{2}{|c|}{$\mathbf{N}$} & \multicolumn{2}{|c|}{$\%$} \\
\hline & & Ya & Tidak & Ya & Tidak \\
\hline 1 & Nama Dokter & 300 & 0 & $100 \%$ & $0 \%$ \\
\hline 2 & SIP Dokter & 245 & 55 & $81,6 \%$ & $18,4 \%$ \\
\hline 3 & Alamat Dokter & 300 & 0 & $100 \%$ & $0 \%$ \\
\hline 4 & No.Telepon Dokter & 298 & 2 & $99,3 \%$ & $0,7 \%$ \\
\hline 5 & Tempat/ Alamat dr. & 300 & 0 & $100 \%$ & $0 \%$ \\
\hline 6 & Tanggal penulisan resep & 291 & 9 & $97 \%$ & $3 \%$ \\
\hline 7 & Tanda R/ & 300 & 0 & $100 \%$ & $0 \%$ \\
\hline 8 & Nama obat & 300 & 0 & $100 \%$ & $0 \%$ \\
\hline 9 & Kekuatan obat & 300 & 0 & $100 \%$ & $0 \%$ \\
\hline 10 & Jumlah obat & 300 & 0 & $100 \%$ & $0 \%$ \\
\hline 11 & Aturan pakai obat & 300 & 0 & $100 \%$ & $0 \%$ \\
\hline 12 & Nama pasien & 297 & 3 & $99 \%$ & $1 \%$ \\
\hline 13 & Umur pasien & 186 & 114 & $62 \%$ & $38 \%$ \\
\hline 14 & Jenis kelamin pasien & 0 & 300 & $0 \%$ & $100 \%$ \\
\hline 15 & Berat badan pasien & 8 & 292 & $2,6 \%$ & $97,4 \%$ \\
\hline 16 & Tinggi badan pasien & 2 & 298 & $0,67 \%$ & $99,33 \%$ \\
\hline 17 & Alamat pasien & 85 & 215 & $28,3 \%$ & $71,7 \%$ \\
\hline 18 & Tanda tangan/paraf Dokter & 299 & 1 & $99,6 \%$ & $0,4 \%$ \\
\hline
\end{tabular}

Tabel 1 menunjukkan, berdasarkan kajian administrasi kelengkapan penulisan nama dokter pada resep anak yang masuk di apotek G mencapai $100 \%$, tempat/alamat dokter $100 \%$, tanda R/ 100\%, nama obat $100 \%$, kekuatan obat $100 \%$, jumlah obat $100 \%$ dan aturan pakai obat $100 \%$. Ketidaklengkapan informasi dalam resep akan berpotensi terjadinya medication error (Mamarimbing et al., 2012). Kelengkapan penulisan nama, kekuatan, jumlah dan aturan pakai obat akan 
mengurangi kesalahan pelayanan resep di apotek, sehingga pasien benar-benar mendapatkan obat sesuai yang diresepkan dokter. Penelitian sebelumnya menjukkan hasil yang hampir sama yaitu kelengkapan penulisan nama dokter mencapai 95,9\%, alamat dokter 99\%, tanda R/ 95,12\%, nama obat 99,96\% dan aturan pakai obat 98,55\% (Marini et al., 2013). Penelitian lain menunujukkan kelengkapan penulisan nama dokter mencapai 94\% dan alamat dokter 99\% (Ismaya et al., 2019).

Kelengkapan penulisan Surat ljin Praktek (SIP) pada resep anak di Apotek G ditemukan pada $81,6 \%$ resep. Penelitian sebelumnya menunjukkan kelengkapan penulisan SIP mencapai 76,8\% (Prawitosari, 2009) dan 72\% (Ismaya et al., 2019). SIP dokter wajib dicantumkan untuk menjamin keamanan pasien, bahwa dokter yang bersangkutan mempunyai hak dan kewajiban yang dilindungi undang-undang dalam memberikan pengobatan. SIP adalah bukti tertulis yang diberikan dinas kesehatan kabupaten/kota kepada dokter dan dokter gigi yang akan menjalankan praktik kedokteran setelah memenuhi persyaratan (Kemenkes RI, 2011).

Kajian administrasi resep diapotek $G$ berdasarkan kelengkapan penulisan nomor telepon dokter mencapai 99,3\%. Penelitian sebelumnya tentang kelengkapan penulisan nomor telepon dokter ditemukan pada $85 \%$ resep yang dilayani (Ismaya et al., 2019). Telepon merupakan salah satu alat komunikasi, dalam hal ini telepon digunakan untuk komunikasi antara apoteker di apotek yang melayani resep dengan dokter penulis resep. Berdasarkan pedoman dari Kementerian Kesehatan jika ditemukan adanya ketidaksesuaian dari hasil pengkajian maka apoteker harus menghubungi dokter penulis resep (Kemenkes RI, 2016).

Kelengkapan penulisan tanggal resep ditemukan pada $97 \%$ resep anak yang masuk di apotek G. Kelengkapan penulisan tanggal dalam resep berdasarkan penelitian sebelumnya menunjukkan hasil 94,6\% (Prawitosari, 2009) dan 98\% (Ismaya et al., 2019). Penulisan tanggal pada resep penting dilakukan karena dengan dicantumkannya tanggal maka keamanan pasien terkait pengambilan obat tersebut akan terjaga (Ismaya et al., 2019).

Nama pasien digunakan untuk verifikasi penyerahan obat untuk menghindari tertukarnya obat dengan pasien lain pada saat pelayanan obat di apotek. Kelengkapan penulisan nama pasien ditemukan pada $99 \%$ resep anak yang masuk di apotek G. Untuk resep yang tidak mancantumkan nama pasien, pihak apotek $\mathrm{G}$ melakukan cross ceck terhadap identias pasien dengan menanyakan alamat pasien pada saat penyerahan obat. Hasil penelitian ini sama dengan hasil penelitian sebelumnya dimana kelengkapan penulisan nama pasien ditemukan pada 99\% resep (Ismaya et al., 2019).

Dari seluruh resep anak yang masuk ke apotek $\mathrm{G}$, kelengkapan penulisan umur ditemukan pada $62 \%$, Berat Badan (BB) 2,6\%, Tinggi Badan (TB) $0,67 \%$ dan Jenis Kelamin (JK) $0 \%$. Informasi BB dalam peresepan dapat digunakan untuk melihat kembali ketepatan dosis obat yang digunakan, dalam beberapa obat, penggunaan dosis harus disesuaikan dengan berat badan pasien, khususnya peresepan obat untuk anak-anak (Cholisoh et al., 2019). Umur dan BB pasien berhubungan dengan pendosisan obat, dalam Drug Information Handbook (DIH) data umur dan BB pasien anak sangat diperlukan untuk penyesuaian dosis (APha's, 2015). Peneliti sebelumnya menemukan kelengkapan penulisan umur ditemukan pada $72 \%$, sedangkan data BB hanya ditemukan pada 1\% resep yang dilayani (Ismaya et al., 2019).

Penulisan alamat pasien ditemukan pada $28,3 \%$ resep yang masuk, di apotek G data alamat pasien diperlukan sebagai pembeda ketika ada 2 atau lebih pasien dengan nama yang sama agar tidak terjadi kesalahan pada saat penyerahan obat. Dibandingkan dengan penelitian sebelumnya, kelengkapan penulisan alamat pasien pada resep yang masuk di apotek $G$ tergolong rendah. Penelitian lain oleh (Ismaya et al., 2019) menemukan kelengkapan penulisan alamat ditemukan pada $99 \%$, sedangkan (Prawitosari, 2009) menemukan sebesar 63,6\%. 
Kelengkapan tanda tangan atau paraf dokter pada resep yang masuk di apotek G ditemukan pada 99,6\% resep. Hasil penelitian (Ismaya et al., 2019) menyebutkan kelengkapan paraf dokter ditemukan dalam 47\% resep. Paraf dokter merupakan salah satu persyaratan adminitrasi yang harus ada dalam resep (Kemenkes RI, 2016). Kelengkapan nama dan paraf dokter dalam resep merupakan hal yang penting untuk menjamin keotentikan resep sehingga dapat dipertanggungjawabkan untuk menentukan keputusan terapi pada pasien selain itu resep obat juga tidak mudah disalahgunakan di masyarakat umum (Pratiwi et al., 2017).

\section{Analisa Resep Berdasarkan Kajian Farmasetis}

Berdasarkan Standar Pelayanan Kefarmasian di Apotek, aspek farmasetik yang harus terpenuhi dari suatu resep adalah: bentuk sediaan, ketersediaan, kekuatan sediaan, stabilitas serta kompatibilitas atau ketercampuran obat. Hasil pengkajian secara farmasetis terhadap resep anak yang masuk di apotek $\mathrm{G}$ tersaji dalam tabel 2. Tabel 2 menunjukkan kesesuaian antara bentuk sediaan dan pasien 100\%, stabilitas obat $100 \%$, cara pakai obat $100 \%$, inkompatibilitas dalam resep $0 \%$. Dapat disimpulkan bahwa seluruh resep anak yang dikaji memenuhi kesesuain farmasetis.

Dalam penelitian ini bentuk sediaan obat yang banyak diresepkan adalah racikan puyer, sirup dan kapsul. Sirup merupakan sediaan yang cocok untuk anakanak, sirup mengandung sukrosa yang dapat digunakan untuk menutupi rasa pahit dari obat selain itu sirup lebih mudah ditelan dibandingkan dengan bentuk sediaan padat seperti tablet atau kapsul (16). Permasalahannya tidak semua obat tersedia dalam bentuk sirup sehingga bebrapa obat perlu digerus terlebih dahulu menjadi bentuk puyer (17). Anak-anak memerlukan bentuk sediaan yang sesuai, rasa obat yang tidak enak menjadi masalah dalam formulasi dan hambatan dalam pemberian obat (18).

Tabel 2. Kajian Farmasetis Resep Anak yang Masuk di Apotek G Kota Madiun Periode Juni sampai Agustus 2019

\begin{tabular}{cccccc}
\hline \multirow{2}{*}{ No } & \multirow{2}{*}{ Aspek Farmasetis } & \multicolumn{3}{c}{ Kelengkapan Farmasetis } \\
\cline { 3 - 6 } & & \multicolumn{3}{c}{$\mathbf{N}$} & \multicolumn{3}{c}{$\%$} \\
\cline { 3 - 6 } & & Ya & Tidak & Ya & Tidak \\
\hline 1 & $\begin{array}{l}\text { Kesesuaian antara bentuk } \\
\text { sediaan dan pasien }\end{array}$ & 300 & 0 & $100 \%$ & $0 \%$ \\
\hline 2 & Stabilitas obat & 300 & 0 & $100 \%$ & $0 \%$ \\
\hline 3 & Cara pakai obat & 300 & 0 & $100 \%$ & $0 \%$ \\
\hline 4 & Inkompatibilitas dalam resep & 0 & 300 & $0 \%$ & $100 \%$ \\
\hline
\end{tabular}

Penelitian sebelumnya (Ismaya et al., 2019) menunjukkan kesesuain farmasetik dari seluruh resep yang dilayani adalah $75 \%$, dari segi kesesuaian stabilitas menunjukkan $99 \%$ terpenuhi stabilitasnya. Penelitian lainnya tentang pengkajian secara farmasetik menunjukkan keseaian bentuk sediaan $69,61 \%$, kekuatan sediaan $57,66 \%$, stabilitas obat $100 \%$ dan kompatibilitas obat $100 \%$ (Rauf et al., 2020). Stabilitas obat merupakan salah satu faktor yang harus diperhatikan karena dapat mempengaruhi efektifitas, keamanan dan mutu obat (Deviarny et al., 2013). Dalam penelitian ini seluruh resep anak yang masuk di apotek $G$ memenuhi persayaratan stabilitas, yang ditunjukkan dengan obat dalam keadaan baik dan tidak terjadi perubahan bentuk, warna dan bau sediaan serta terjadi kerusakan pada kemasan obat.

Dalam penelitian ini, instruksi cara pakai obat dalam semua resep sesuai untuk pasien anak serta tidak ditemukan permasalah inkompatibilitas. Cara pemberian atau cara pakai obat yang tepat merupakan salah satu ciri penggunaan obat rasional. Cara pemberian obat memerlukan pertimbangan dosis, frekuensi pemberian, dan lama 
pemberian sampai ke pemilihan cara pemakaian yang paling mudah diikuti pasien, aman, dan efektif untuk pasien (Staff Pengajar FK Unsri, 2009).

\section{Kesimpulan}

Pengkajian secara administrasi terhadap resep anak yang masuk di apotek $\mathrm{G}$ periode Juni sampai Agustus 2019 menunjukkan kelengkapan penulisan nama dokter $100 \%$, tempat atau alamat dokter $100 \%$, tanda R/ 100\%, nama obat $100 \%$, kekuatan obat $100 \%$, jumlah obat $100 \%$, aturan pakai obat $100 \%$, tanda tangan atau paraf dokter $99,6 \%$, no.telepon dokter $99,3 \%$, nama pasien $99 \%$, tanggal penulisan resep $97 \%$, SIP dokter $81,6 \%$, umur pasien $62 \%$, alamat pasien $28,3 \%$, iter/ tanda lain $6,3 \%$, berat badan pasien $2,6 \%$, tinggi badan pasien $0,67 \%$, jenis kelamin pasien $0 \%$, sedangkan berdasarkan pengkajian farmasetis menunjukkan kesesusian antara bentuk sediaan dan pasien $100 \%$,stabilitas obat $100 \%$, cara pakai obat $100 \%$, inkompatibilitas dalam resep $0 \%$.

\section{Ucapan Terimakasih}

Terimakasih kepada keluarga besar apotek $\mathrm{G}$ yang telah memberi kesempatan untuk kami melakukan penelitian, Universitas Sahid Surakarta yang telah memfasilitasi penelitian ini serta kepada tim penelitian yang luar biasa, bu Ayu dan bu Ima.

\section{Daftar Pustaka}

APha's. (2015). Drug Information Handbook (24th ed.). Lexicomp.

Cholisoh, Z., Damayanti, A., \& Sari, D. N. (2019). Kualitas Penulisan Resep untuk Pasien Pediatri di Rumah Sakit Surakarta. Urecol, 973-977.

Depkes RI. (2009). Pedoman Pelayanan Farmasi Untuk Pasien Pediatr.

Deviarny, C., Lucida, H., \& Safni, S. (2013). Uji Stabilitas Kimia Natrium Askorbil Fosfat Dalam Mikroemulsi Dan Analisisnya Dengan HPLC. Jurnal Farmasi Andalas, 1.

Ismaya, N., Tho, I., \& Fathoni, M. (2019). Gambaran Kelengkapan Resep Secara Administratif Dan Farmasetik Di Apotek K24 Pos Pengumben. Edu Masda Journal, 3.

Jas, A. (2009). Perihal Resep \& Dosis serta Latihan Menulis Resep. (2nd ed.). Universitas Sumatera Utara Press.

Kemenkes RI. (2011). Peraturan Menteri Kesehatan Republik Indonesia Nomor 2052/MENKES/PER/X/2011 Tentang Izin Praktik Dan Pelaksanaan Praktik Kedokteran.

Kemenkes RI. (2014). Peraturan Menteri Kesehatan Republik Indonesia Nomor 58 Tahun 2014 Tentang Standar Pelayanan Kefarmasian Di Rumah Sakit.

Kemenkes RI. (2016). Peraturan Menteri Kesehatan Republik Indonesia Nomor 73 Tahun 2016 Tentang Standar Pelayanan Kefarmasian Di Apotek.

Kemenkes RI. (2019). Petunjuk Teknis Standar Pelayanan Kefarmasian Di Apotik.

Mamarimbing, M., Fatimawali, F., \& Bodhi, W. (2012). Evaluasi Kelengkapan Administratif Resep dari Dokter Spesialis Anak Pada Tiga Apotek di Kota Manado. Pharmacon.

Marini, Iswahyudi, \& Wijianto, B. (2013). Analisis kelengkapan Penulisan Resep Dari Aspek Kelengkapan Resep Di Apotek Kota Pontianak Tahun 2012. Jurnal Mahasiswa Farmasi Fakultas Kedokteran UNTAN, 1.

Piliarta, I. N., Swastini, D. A., \& Noviyani, R. (2012). Kajian Kelengkapan Resep 
Pediatri Rawat Jalan Yang Berpotensi Menimbulkan Medication Error Di Rumah Sakit Swasta Di Kabupaten Gianyar. Jurnal Farmasi Udayana, 1.

Pratiwi, D., M, N. R. I., \& Pratiwi, D. R. (2017). Analisis Kelengkapan Administratif Resep di Apotek Bhumi. 6(35), 6-11.

Prawitosari, D. (2009). Tinjauan Aspek Legalitas Dan Kelengkapan Resep Di 5 Apotek Kabupaten Klaten Tahun 2007. Universitas Muhammadiyah Surakarta.

Rauf, A., Ika, A., \& Jannah, M. (2020). Kajian Skrining Resep Aspek Administratif Dan Farmasetik Di Apotek CS Farma Periode Juni-Desember 2018 Study of Prescription Screening for Administratives and Pharmaceuticals Aspects at CS Farma Pharmacy in the Period June-December 2018 Medication error m. AdDawaa' Journal of Pharmaceutical Sciences, 3(0), 33-39. https://doi.org/10.24252/djps.v3i1.14007

Staff Pengajar FK Unsri. (2009). Kumpulan Kuliah Farmakologi Edisi 2. Penerbit Buku Kedokteran, Universitas Sriwijaya. 